\title{
El Astillero and EI Pedregal \\ monogenetic volcanoes (Michoacán, Mexico): a multi- isotopic study of the eruptive sequence
}

\author{
P. LARREA ${ }^{1,2 *}$, E. WIDOM ${ }^{2}$, C. SIEBE $^{3}$, D. PARRA ${ }^{1}$, S. \\ SALINAS $^{4}$ \\ ${ }^{1}$ Department of Geology and Andean Geothermal Center of \\ Excellence (CEGA), Facultad de Ciencias Físicas y \\ Matemáticas, Universidad de Chile, Santiago, Chile; \\ *plarrea@ing.uchile.cl \\ ${ }^{2}$ Department of Geology \& Environmental Earth Science, \\ Miami University, Oxford, OH, USA \\ ${ }^{3}$ Departamento de Vulcanología, Instituto de Geofísica, \\ Universidad Nacional Autónoma de México, Ciudad de \\ México, México \\ ${ }^{4}$ Facultad de Ingeniería, División de Ingeniería en Ciencias de \\ la Tierra, Universidad Nacional Autónoma de México, \\ Ciudad Universitaria, Ciudad de México, México
}

El Astillero and El Pedregal monogenetic volcanoes are located in the southwestern part of the Michoacán Guanajuato Volcanic Field, only $25 \mathrm{~km}$ to the south of the historic Paricutin volcano. El Astillero and El Pedregal erupted between AD 500-700, first forming the El Astillero scoria cone and tephra deposits, followed by its a lava field, and ending with the emplacement of the El Pedregal viscous lavas [1]. During the $\sim 6$ years of eruption, both volcanoes occupied an area of $\sim 15 \mathrm{~km}^{2}$ and emitted $\sim 0.5 \mathrm{~km}^{3}$ (DRE) of magma. Notable characteristics of the eruptions include a change from explosive (Strombolian) to effusive activity, a shift in the active vents, and a progressive change in the bulk magma composition from basaltic andesite to andesite, followed by a final reversal to intermediate composition in the last emitted lava flows.

A selection of representative tephras and lavas from this cluster have been analyzed for $\mathrm{Sr}-\mathrm{Nd}-\mathrm{Pb}$ isotopic systems. Our preliminary results show that El Astillero and El Pedregal samples exhibit similar isotopic trends to that of the primitive lavas and tephras from Paricutin, which are interpreted as mantle-derived signatures [2]. We are also pursuing $\mathrm{Os}$, $\mathrm{Hf}$ and high-precision $\mathrm{Pb}$ isotope analyses to further evaluate the relative role of crustal assimilation versus mantle source heterogeneity in the evolution of this volcanic cluster.

[1] Larrea et al. (2019) Chem. Geol. 504, 66-82. [2] Larrea et al. (2018) Bull. Volcanol. 81:59. 